\title{
Influence of Soil Fertility Management on Nitrogen Mineralization, Urease Activity and Maize Yield
}

\author{
Daniel M. Kalala ${ }^{1}$, Victor Shitumbanuma ${ }^{1}$, Benson H. Chishala ${ }^{1}$, Alice M. Mweetwa ${ }^{1}$ \& Andreas Fliessbach ${ }^{2}$ \\ ${ }^{1}$ School of Agricultural Sciences, Soil Science Department, University of Zambia, Great East Road Campus, \\ Lusaka, Zambia \\ ${ }^{2}$ Research Institute of Organic Agriculture (FiBL), Frick, Switzerland \\ Correspondence: Daniel M. Kalala, School of Agricultural Sciences, Soil Science Department, University of \\ Zambia, Great East Road Campus, P.O. Box 32379, Lusaka, Zambia. Tel: 260-977-749-368. E-mail: \\ danielkalala2@gmail.com
}

Received: October 11, 2021

Accepted: January 4, 2022

Online Published: January 15, 2022

doi:10.5539/jas.v14n2p9

URL: https://doi.org/10.5539/jas.v14n2p9

\begin{abstract}
For studying the effect of soil fertility management practices on $\mathrm{N}$ mineralization, urease activity and maize yield, replicated field trials were established in 2015 at Misamfu and Msekera agricultural research stations (ARS) representing two geo-climatic regions of Zambia. The soil at Msekera ARS is a sandy clay loam (SCL) from a Paleustult, while that at Misamfu is a loamy sand (LS) from a Kandiustult. The field trials had three categories of treatments namely legumes, traditional and conventional. The legumes group consisted of researcher-recommended legume-cereal intercrop systems of maize with Cajanus cajan, Crotalaria juncea and Tephrosia vogelii in combination with compound $\mathrm{D}\left(10 \% \mathrm{~N}, 20 \% \mathrm{P}_{2} \mathrm{O}_{5}, 10 \% \mathrm{~K}_{2} \mathrm{O}\right)$ and urea $(46 \% \mathrm{~N})$ at the recommended rate $\left(200 \mathrm{~kg} \mathrm{ha}^{-1}\right)$ and half of the recommended rate $\left(100 \mathrm{~kg} \mathrm{ha}^{-1}\right)$. Composted cattle manure and Fundikila, a special plant biomass management technique, were the inputs under the traditional category. The conventional category consisted of a treatment to which only chemical fertilizer was applied. Urease activity was determined in surface soil samples $(0-20 \mathrm{~cm})$ collected from the field trials after 3 years. For $\mathrm{N}$ mineralization, a laboratory incubation study was conducted over 13 weeks. For the laboratory incubation, an additional treatment to which no input was applied was included as control. Application of organic inputs significantly increased the potentially mineralizable $\mathrm{N}\left(\mathrm{N}_{\mathrm{o}}\right)$ by $127 \%$ to $256 \%$ on the LS and by $51 \%$ to $131 \%$ on the SCL in comparison to the control. Similarly, the cumulative $\mathrm{N}$ mineralized $\left(\mathrm{N}_{\text {cum }}\right)$ was twice or thrice higher where organic inputs had been applied in comparison to the control. The $\mathrm{N}_{\mathrm{o}}$ followed the order traditional $>$ legumes $>$ conventional $>$ control, while the mineralization rate constant $(\mathrm{k})$ followed the order legumes $>$ conventional $>$ traditional $>$ control on both soils. The rate of N mineralization was significantly higher on the LS than the SCL. Higher rates of chemical fertilizer resulted in high $\mathrm{N}_{\text {cum }}$ and higher maize yield. Maize yield was significantly and positively correlated to $\mathrm{N}_{\text {cum }}$, but inversely correlated to the amount of applied $\mathrm{N}$ that was mineralized $\left(\% \mathrm{~N}_{\min }\right)$. Urease activity was stimulated by application of organic inputs and suppressed by higher rates of chemical fertilizers. The type of organic inputs; the rate of chemical fertilizers; and soil texture are factors influencing $\mathrm{N}$ mineralization and maize yield. Urease activity was largely influenced by the rate of chemical fertilizer, but not the type of organic inputs or soil texture.
\end{abstract}

Keywords: nitrogen mineralization, urease, organic inputs, chemical fertilizer

\section{Introduction}

Nitrogen is probably the most important nutrient for crop production as it is normally taken-up in higher amounts than any other nutrient (Bhat, Saroa, Benbi, Choudary, \& Padder, 2015), and is known to limit primary production in most terrestrial ecosystems (Sekaran, McCoy, Kumar, \& Subramanian, 2019; Cartes, Alejandra, Damanet, \& Mora, 2009). There are many N management practices used by farmers to meet the crop N demand. Whilst the use of chemical fertilizer is probably the most widespread practice among commercial farmers, the high cost and increasing environmental concerns have pushed most resource-poor smallholder farmers in Zambia and other parts of Africa to use organic inputs as a cost-effective and sustainable alternative for providing nitrogen to the crop (Kiboi, Ngetich, \& Mugendi, 2019). As opposed to chemical fertilizers whose nitrogen release to crops can be predicated with some degree of certainty, the mechanism of $\mathrm{N}$ uptake by crops from 
applied organic inputs is very complex and varies widely. One of the reasons for this is that for the nitrogen contained in organic inputs to be available for crop uptake, it has to be converted from the organic to the inorganic form through a process called nitrogen mineralization (Hart, Stark, Davidson, \& Firestone, 1994).

During the mineralization process, large organic molecules are broken down by hydrolytic enzymes that transform the organic $\mathrm{N}$ to plant available forms (Karuku \& Mochoge, 2018). There are many different hydrolytic enzymes in the soil that make nutrients available to plants. Depending on their location, these enzymes can be categorized as extracellular or intra-cellular (Srinivasa-Rao et al., 2017; Piotrowska-Dlugosz, 2014). An exoenzyme or extracellular enzyme is an enzyme that is secreted by a cell and functions outside that cell. These enzymes break-down organic molecules such as lignin, cellulose, hemicellulose and urea, outside the body of the organism. Endoenzymes or intracellular enzymes on the other hand, function within the cells of the organism (Insam, 2001). Among many soil enzymes that catalyse different soil biological processes, urease, an extracellular enzyme, is particularly important in the nitrogen cycle (Dilly, Blume \& Munch, 2003; Piotrowska-Dlugosz, 2014) as it is involved in the hydrolytic conversion of organic $\mathrm{N}$ into plant available forms. An understanding of the influence of different soil fertility management practices on the activity of urease is thus vital in understanding the $\mathrm{N}$ mineralization process.

Whilst a number of studies have been carried out to investigate the effects of different soil fertility management on $\mathrm{N}$ transformation and $\mathrm{N}$ availability, the mechanisms of nitrogen mineralization from organic inputs in traditional and experimental cropping systems, however, have not been extensively studied on Zambian soils. Particularly, little information is available on the response of urease activity and nitrogen mineralization to the organic inputs commonly used on Zambian soils. This study was conducted to determine the influence of different organic inputs with or without chemical fertilizer on nitrogen mineralization, urease activity and maize yield. We hypothesized that: (i) the application of organic inputs will enhance urease activity and increase the rate of $\mathrm{N}$ mineralization and maize yield; (ii) the feedback to the application of chemical fertilizer and the presence of inorganic $\mathrm{N}$ will reduce the rate of $\mathrm{N}$ mineralization and suppress urease activity; (iii) the soil texture would influence the $\mathrm{N}$ mineralization rate, the activity of urease enzyme and consequently maize yield.

\section{Materials and Method}

The research work consisted of field trials carried out in two contrasting geo-climatic regions of Zambia and an incubation experiment conducted in the laboratory at the University of Zambia.

\subsection{Field Trials}

\subsubsection{Site Description}

Field trials were conducted at Misamfu $\left(10^{\circ} 10^{\prime} 09.36^{\prime \prime} \mathrm{S} ; 31^{\circ} 14^{\prime} 24.92^{\prime \prime} \mathrm{E}\right)$ and Msekera $\left(13^{\circ} 38^{\prime} 43.17^{\prime \prime} \mathrm{S}\right.$; $32^{\circ} 33^{\prime} 38.93^{\prime \prime E}$ ) Agricultural Research Stations (ARSs) starting in November 2015. Misamfu ARS, in the Northern Province of Zambia, lies in agroecological region III where the average annual rainfall is in excess of $1000 \mathrm{~mm}$. Msekera ARS, in the Eastern Province of Zambia is located in agroecological region IIa with average annual rainfall ranging from 800 to $1000 \mathrm{~mm}$ (Figure 1). The soil at Misamfu ARS is characterized as Kandiustult with a loamy sand surface horizon, while that at Msekera ARS is classified as Paleustult (Veldkamp, 1987) with a sandy clay loam surface horizon (Magai, 1985). The two soils are representative of extensively cultivated agricultural soils in the respective regions. 


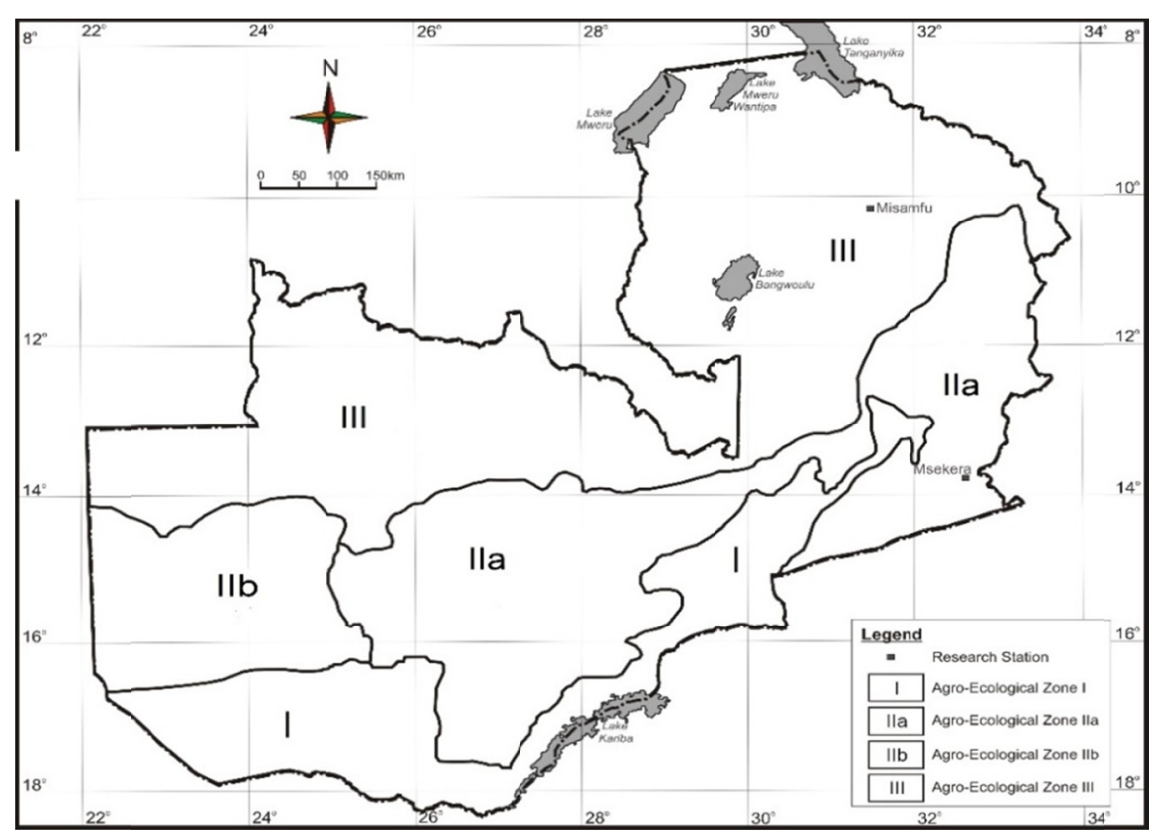

Figure 1. Map of Zambia showing the agro-ecological regions and locations of Misamfu and Msekera ARS

\subsubsection{Experimental Design, Treatment Description and Management of Field Trials}

The field experiment was laid out in a randomized complete block design (RCBD) in $10 \times 10 \mathrm{~m}$ plots with four replicates at Misamfu ARS and five replicates at Msekera ARS. There were eight treatments at Misamfu ARS and nine treatments at Msekera ARS. The treatments used in the field trials were informed by a Participatory Rural Appraisal that was conducted to identify potential soil fertility management practices suitable for small-scale farmers in the two sites based on recommendations by farmers or researchers.

Legume-cereal intercrop systems of maize with Cajanus cajan (pigeon peas), Tephrosia vogelii (tephrosia) and Crotalaria juncea (black sunnhemp) constituted the researcher-recommended fertility management practices tested. All the intercrop systems were assessed in combination with "Compound D" chemical fertilizer $(10 \% \mathrm{~N}$; $\left.20 \% \mathrm{P}_{2} \mathrm{O}_{5} ; 10 \% \mathrm{~K}_{2} \mathrm{O}\right)$ used as a basal dressing fertilizer and urea $(46 \% \mathrm{~N})$ used as a top-dressing fertilizer. Both chemical fertilizers were applied at full and half of their recommended rate for small-scale farmers in Zambia (Table 1). The traditional soil fertility management practices consisted of the Fundikila system at Misamfu ARS, while at Msekera ARSs it was the use of composted cattle manure (Table 1). The Fundikila system is a traditional farming practice, which involves burying native grasses and shrubs in big ridges towards the end of the growing season about end of March to early April. The ridges are opened-up and flattened before the onset of the next rainy season sometime in early December and the crop is then planted. A modified version of the traditional Fundikila system, which consisted of burying velvet beans (Mucuna pruriens) biomass grown for three to four months instead of the native grasses and shrubs was included at Misamfu ARS. The traditional Fundikila was tested in combination with the full rates of compound D and urea fertilizers to represent the farmers' practice, while the modified Fundikila was assessed with half and full of the recommended rates of Compound D and urea fertilizers (Table 1). The composted cattle manure was used alone or in combination with half of the recommended rate of Compound D fertilizer. A conventional treatment consisting of a maize monocrop with full rates of Compound D and urea was included in both sites as a control treatment (Table 1). 
Table 1. Codes and description of treatments used in the field study at Misamfu and Msekera ARS

\begin{tabular}{|c|c|c|c|c|c|}
\hline & & \multirow{2}{*}{ Treatment Code } & \multirow{2}{*}{ Treatment description } & \multicolumn{2}{|c|}{$\begin{array}{c}\text { Amount }(\mathrm{kg} / \mathrm{ha}) \text { and type } \\
\text { of fertilizer applied }\end{array}$} \\
\hline & & & & $\begin{array}{l}\text { Compound D } \\
(\mathrm{N} 10 \text { P20 K10) }\end{array}$ & Urea (N46) \\
\hline \multirow{9}{*}{ Msekera ARS } & $\mathrm{T} 1$ & PpF1 & Pigeon pea-maize intercrop system; full rate of chemical fertilizer & 200 & 200 \\
\hline & $\mathrm{T} 2$ & $\mathrm{PpF}_{1 / 2}$ & Pigeon pea-maize intercrop system; half rate of chemical fertilizer & 100 & 100 \\
\hline & $\mathrm{T} 3$ & TepF1 & Tephrosia-maize intercrop system; full rate of chemical fertilizer & 200 & 200 \\
\hline & $\mathrm{T} 4$ & $\mathrm{TepF}_{1 / 2}$ & Tephrosia-maize intercrop system; half rate of chemical fertilizer & 100 & 100 \\
\hline & T5 & Conv & Conventional treatment; full rate of chemical fertilizer & 200 & 200 \\
\hline & T6 & $\operatorname{ManF}_{1 / 2}$ & Composted cattle manure; half rate of Compound D fertilizer & 100 & 0 \\
\hline & $\mathrm{T} 7$ & ManF0 & Composted cattle manure; no chemical fertilizer & 0 & 0 \\
\hline & T8 & SunF1 & Sunnhemp-maize intercrop system; full rate of chemical fertilizer & 200 & 200 \\
\hline & T9 & $\operatorname{SunF}_{1 / 2}$ & Sunnhemp-maize intercrop system; half rate of chemical fertilizer & 100 & 100 \\
\hline \multirow{8}{*}{ Misamfu ARS } & $\mathrm{T} 1$ & PpF1 & Pigeon pea-maize intercrop system; full rate of chemical fertilizer & 200 & 200 \\
\hline & $\mathrm{T} 2$ & $\mathrm{PpF}_{1 / 2}$ & Pigeon pea-maize intercrop system; half rate of chemical fertilizer & 100 & 100 \\
\hline & $\mathrm{T} 3$ & TepF1 & Tephrosia-maize intercrop system; full rate of chemical fertilizer & 200 & 200 \\
\hline & T4 & $\mathrm{TepF}_{1 / 2}$ & Tephrosia-maize intercrop system; half rate of chemical fertilizer & 100 & 100 \\
\hline & T5 & Conv & Conventional treatment; full rate of chemical fertilizer & 200 & 200 \\
\hline & T6 & $\operatorname{ModF}_{1 / 2}$ & Modified Fundikila; half rate of chemical fertilizer & 100 & 100 \\
\hline & $\mathrm{T} 7$ & ModF0 & Modified Fundikila; no chemical fertilizer & 0 & 0 \\
\hline & $\mathrm{T} 8$ & TradF1 & Traditional Fundikila; full rate of chemical fertilizer & 200 & 200 \\
\hline
\end{tabular}

Note. Incubation experiment: a treatment to which no input was added was included as control (Cont) on both soils.

The pigeon peas and tephrosia were planted in the 2015/16 season at the on-set of the rainy season and remained as permanent interplants with occasional gapping in subsequent seasons. The herbaceous legumes (velvet beans and sunnhemp), on the other hand, were planted every season. In the 2015/16 season, the velvet beans used in the modified Fundikila was planted at the onset of the rainy season as a sole crop, whilst in the 2016/17 and 2017/18 seasons, it was planted two weeks after maize emergence in-between the maize rows. After maize harvest, the biomasses of velvet beans and the maize stover were buried in the Fundikila ridges. In all the three seasons the sunnhemp was planted two weeks after maize emergence in-between the maize rows. The tephrosia and pigeon peas were trimmed 3 to 4 times in the 2016/17 and 2017/18 seasons to a height of 30 to $60 \mathrm{~cm}$ to reduce competition with the maize crop and to return the biomass to the soil. No trimming was done in the 2015/16 season as both the tephrosia and pigeon peas were too young and were still establishing. The sunnhemp was trimmed once or twice during the growing season in all the three years. The native grasses and shrubs used in the traditional Fundikila system was only allowed to grow in the 2015/16 season using the traditional fallow approach. In the 2016/17 and 2017/18 seasons, the traditional Fundikila was done by burying in big ridges, the maize residues and the weeds that would be left on the plot after maize harvest.

\subsubsection{Basic Characterization of Organic Inputs}

The composted cattle manure and leaves and twigs of tephrosia, pigeon pea, sunnhemp and velvet beans were air-dried under a shade for a week and then oven-dried for 48 hours at $65{ }^{\circ} \mathrm{C}$. The materials were then milled using a Thomas-Wiley Laboratory mill model 4 and sieved on a $2 \mathrm{~mm}$ mesh size sieve. Total nitrogen was determined using the salicyclic-thiosulphate method as described by Amin and Flowers (2004). To determine total potassium and total phosphorus, $1 \mathrm{~g}$ of the ground biomass was extracted with $20 \mathrm{ml}$ of $1 \mathrm{~N}$ nitric acid after incineration at $450{ }^{\circ} \mathrm{C}$ for 2 hours (Jones, 2001). Concentrations of potassium in the extract were determined by flame emission on a Perkin Elmer Analyst 400 Atomic Absorption spectrophotometer, while concentrations of phosphorus were determined using a JENWAY $6305 \mathrm{UV} /$ Visible spectrophotometer at a wavelength of $882 \mathrm{~nm}$. The organic carbon content of the plant materials was determined by the Walkley and Black method (Schumacher, 2002). Selected properties of the inputs used in the study are presented in Table 2. To estimate the amount of biomass that the different plants returned to the soil, the quadrat method of Anderson and Ingram (1993) was used. A 0.5 by $0.5 \mathrm{~m}$ wooden frame was used to sample the plant materials. To avoid soil contamination, the plants were cut at $2 \mathrm{~cm}$ from the ground, air-dried under a shade for a week and then oven-dried for 48 hours at $65^{\circ} \mathrm{C}$, and thereafter, weighed. 
Table 2. Mean values of the parameters of the organic inputs used in the experiment

\begin{tabular}{lllccc}
\hline Organic input & $\mathrm{N}$ & $\mathrm{K}$ & $\mathrm{P}$ & $\mathrm{C}$ & $\mathrm{C} / \mathrm{N}$ ratio \\
\hline & $----\mathbf{y}^{-}$ & 2.00 & 0.36 & 35.16 & 18.8 \\
Composted cattle manure & 1.87 & 2.03 & 0.16 & 49.20 & 44.3 \\
Indigenous biomass & 1.11 & 1.72 & 0.22 & 56.48 & 25.3 \\
Pigeon peas & 2.23 & 0.99 & 0.21 & 51.44 & 18.1 \\
Tephrosia & 2.84 & 1.47 & 0.33 & 54.48 & 17.1 \\
Sunnhemp & 3.18 & 2.30 & 0.38 & 53.36 & 15.0 \\
Velvet beans & 3.56 & &
\end{tabular}

\subsubsection{Soil Chemical Analyses}

At the start of the field trials, soil samples collected to a depth of $0-20 \mathrm{~cm}$ using bucket augers measuring $8 \mathrm{~cm}$ in diameter, were analysed for selected chemical properties. Between 15 to 20 individual samples collected across the field were mixed to form one composite sample. At Msekera the trial field was subdivided into 5 blocks based on the slope of the terrain, while at Misamfu, the field was subdivided into 4 blocks. One composite sample was collected per block at each site. The composite samples were air-dried and passed through a $2 \mathrm{~mm}$ mesh size sieve, then stored under dry conditions at room temperature prior to the analyses. The soil samples were analysed for $\mathrm{pH}$ in $0.01 \mathrm{M} \mathrm{CaCl}_{2}$; organic carbon using the potassium dichromate wet oxidation method (Nelson \& Sommers, 1982); total nitrogen $(\mathrm{N})$ using the Kjeldahl method (Jones, 2001) after digesting the samples in concentrated $\mathrm{H}_{2} \mathrm{SO}_{4}$; available phosphorus (P) using the Bray 1 method (Jones, 2001); and exchangeable potassium $(\mathrm{K})$ using $1 \mathrm{M}$ ammonium acetate as extractant. The particle size distribution was determined using the hydrometer method (Jones, 2001) and bulk density using the core ring method (Anderson and Ingram, 1993). Table 3 presents selected chemical and physical properties of the soils at Msekera and Misamfu ARS.

Table 3. Mean values with standard errors of selected properties of soils used in the study

\begin{tabular}{|c|c|c|}
\hline Soil Property & Msekera & Misamfu \\
\hline USDA Textural class & Sandy clay loam & Loamy Sand \\
\hline $\mathrm{pH}\left[0.01 \mathrm{M} \mathrm{CaCl}_{2}\right]$ & $4.39 \pm 0.04$ & \pm 0.04 \\
\hline Organic matter $[\%]$ & $2.42 \pm 0.12$ & $2.53 \pm 0.15$ \\
\hline Bray1- phosphorus [mg kg-1 soil] & $5.38 \pm 0.43$ & $25.15 \pm 0.17$ \\
\hline Exchangeable potassium $\left[\mathrm{cmol} \mathrm{kg} \mathrm{soil}{ }^{-1}\right]$ & $0.69 \pm 0.02$ & \pm 0.06 \\
\hline Total nitrogen [\%] & $0.03 \pm 0.01$ & \pm 0.01 \\
\hline Bulk Density $\left[\mathrm{Mg} \mathrm{m}^{-3}\right]$ & $1.48 \pm 0.03$ & \pm 0.00 \\
\hline Sand $[\%]$ & $58.8 \pm 1.3$ & \pm 0.4 \\
\hline Silt $[\%]$ & $14.0 \pm 1.3$ & \pm 0.4 \\
\hline Clay $[\%]$ & $27.2 \pm 1.0$ & 10.8 \\
\hline
\end{tabular}

\subsubsection{Determination of Urease Activity}

Soil samples collected from field trials to a depth of $0-20 \mathrm{~cm}$ at the end of the third year, were passed through a $2 \mathrm{~mm}$ mesh size and stored at $4{ }^{\circ} \mathrm{C}$ prior to the laboratory assays. Urease activity was determined using the buffered short-term assay procedure given by Kandeler and Gerber (1988). Five grams (5 g) of soil placed in $100 \mathrm{ml}$ glass container was wetted with $2.5 \mathrm{ml}$ urea solution and $20 \mathrm{ml}$ borate buffer. The container was stoppered and incubated at $37^{\circ} \mathrm{C}$ for 2 hours. After 2 hours, $30 \mathrm{ml}$ of $1 \mathrm{M} \mathrm{KCl}$ solution was added and the flask was shaken for 30 minutes. The suspension was then filtered and diluted 10 times with distilled water. Ammonium concentration was determined through a modified Berthelot reaction by adding to the filtrate $5 \mathrm{ml}$ of Na-salicyclate/ $\mathrm{NaOH}$ and $2 \mathrm{ml}$ of Na-dichloroisocyanide and allowing to stand at room temperature for 30 minutes. The optical density was measured at $690 \mathrm{~nm}$ on a Skalar Analytical B.V. 4800. Urease activity was found by determining the amount of ammonium nitrogen as given by Equation 1 below:

$$
\text { Urease activity }\left(\text { ug } \mathrm{NH}_{4}-\mathrm{N} \mathrm{g}^{-1} \mathrm{~h}^{-1}\right)=[(\mathrm{S}-\mathrm{B}) \times \mathrm{V} \times 10] /(2 \times \mathrm{dwt})
$$

Where, $\mathrm{S}$ is the ammonium-N concentration ( $\mathrm{ug} \mathrm{NH}_{4}-\mathrm{N} \mathrm{ml}^{-1}$ ) in the sample; $\mathrm{B}$ is the ammonium-N concentration (ug $\mathrm{NH}_{4}-\mathrm{N} \mathrm{ml}^{-1}$ ) in the blank; $\mathrm{V}$ is the total volume of the extract; 10 is the dilution factor; 2 is the duration of the incubation; dwt is the weight of the soil used on a dry basis. 


\subsubsection{Maize Yield Assessment}

Maize cobs were manually harvested at physiological maturity, approximately 1300 days after planting. The maize cobs were sun-dried, shelled and weighed at the end of each growing season. From each main plot, maize cobs were harvested from three subplots of $6 \mathrm{~m}^{2}$ in dimension. The two outer rows on all four sides of the main plots were not considered when setting-up the sub-plots. The moisture content of the maize grain was determined using a moisture meter and the final grain weights were determined when the moisture content was at $12.5 \%$.

\subsection{Incubation Experiment}

The incubation experiment for $\mathrm{N}$ mineralization was carried out in the laboratory at the University of Zambia over a period of 13 weeks. Soil collected from Misamfu and Msekera ARS at a depth of 0-20 cm was air-dried and passed through a $2 \mathrm{~mm}$ mesh-size sieve prior to incubation. $250 \mathrm{~g}$ of the soil was mixed with organic biomass with or without chemical fertilizer at rates equivalent to those used in the field trials (Table 1) and placed in $1 \mathrm{~L}$ jars with screw caps. The rates of the plant biomasses used were based on the average amount of biomass that the different plant species returned to the soil per year as determined from the field trials (Table 4). For the composted cattle manure treatment, a rate equivalent to 20 tons/ha was used. A treatment to which only chemical fertilizer was applied was included to mimic the conventional farming system, while a treatment consisting of soil alone with no addition of organic or chemical fertilizers was used as a control. A The experiment was arranged in a randomized complete block design (RCBD) with four replicates. The average room temperature during the incubation experiment was $22{ }^{\circ} \mathrm{C}$. To ensure that aerobic conditions were maintained, the jars were aerated for 10 minutes after every three days. The moisture content was kept at $60 \%$ of the total porosity of the soil by weighing each jar at each sampling date and adding the required amount of water with a pipette. The total porosity was estimated indirectly from the soil's particle and bulk densities as shown in Equation 2.

$$
\text { Total soil porosity }(\%)=[(\delta \mathrm{s}-\delta \mathrm{b}) / \delta \mathrm{s}] \times 100
$$

Where, $\delta \mathrm{s}=$ soil particle density in $\mathrm{g} \mathrm{cm}^{3-1}$, i.e., $2.65 \mathrm{~g} \mathrm{~cm}^{3-1} ; \delta_{\mathrm{b}}=$ soil bulk density in $\mathrm{g} \mathrm{cm}^{3-1}$.

The amount of $\mathrm{N}$ mineralized from the treatments was determined by taking out $5 \mathrm{~g}$ of incubated soil from the jar and extracting with $50 \mathrm{ml}$ of $2 \mathrm{M} \mathrm{KCl}$ and the $\mathrm{NH}_{4}{ }^{+}-\mathrm{N}$ and $\mathrm{NO}_{3}{ }^{-} \mathrm{N}$ in the filtrate determined by distillation after addition of $\mathrm{MgO}$ and Devarda's alloy and titrating with $0.005 \mathrm{M} \mathrm{HCl}$. Mineralized $\mathrm{N}\left(\mathrm{NH}_{4}{ }^{+}-\mathrm{N}^{-}\right.$and $\left.\mathrm{NO}_{3}{ }^{-} \mathrm{-}\right)$ was determined 2 hours after commencement of the incubation experiment to reflect the initial $\mathrm{N}$ mineralized. Thereafter, mineralized $\mathrm{N}$ was determined weekly up to the ninth week, and then fortnightly up to the end of the experiment $\left(13^{\text {th }}\right.$ week). The concentration of mineralized $\mathrm{N}$ was determined according to Equation 3 .

$$
\mathrm{N}_{\text {min }}=\left(\mathrm{V}_{\mathrm{s}}-\mathrm{V}_{\mathrm{b}}\right) \mathrm{ml} \times 0.005 \mathrm{meq} \mathrm{ml}^{-1} \times 14.01 \mathrm{mg} \mathrm{meq}^{-1} \times 2 \times 1000 \mathrm{~g} \mathrm{~kg}^{-1} \times 1 /[(1-\mathrm{Hf}) \times \mathrm{g} \text { dry soil }]
$$

Where, Nmin is the amount of nitrogen mineralized in $\mathrm{mg} \mathrm{kg}^{-1} ; \mathrm{V}_{\mathrm{s}}=$ volume of $\mathrm{KCl}$ added to the sample; $\mathrm{V} 0=$ volume of $\mathrm{KCl}$ added to the blank; $14.01 \mathrm{mg} \mathrm{meq}^{-1}$ is the atomic weight of nitrogen; 2 is the dilution factor; $\mathrm{Hf}$ $=\%$ water content in soil sample.

The potentially mineralizable nitrogen $\left(\mathrm{N}_{\mathrm{o}}\right)$, defined as the quantity of soil organic $\mathrm{N}$ that is susceptible to mineralization according to first-order kinetics (Karuku and Mochoge, 2018; Stanford, Carter \& Smith, 1974), and the mineralization rate constant $(\mathrm{k})$ were estimated with the assumption that nitrogen mineralization was a first order reaction (Equation 4) (Bhat, Saroa, Benbi, Choudary \& Padder, 2015; Mikha, Rice \& Benjamin, 2006) Estimates of potentially mineralizable nitrogen and $\mathrm{N}$ mineralization rate constant were determined by non-linear least-square regression (Benedetti \& Sebastiani, 1996) using the Marquardt option of nonlinear curve fitting procedure in SAS version 9.0 and confirmed using SigmaPlot version 11.0.

$$
\mathrm{N}_{\mathrm{f}}=\mathrm{N}_{\mathrm{o}}\left(1-\mathrm{e}^{-\mathrm{kt}}\right)
$$

Where, $\mathrm{N}_{\mathrm{f}}$ is the cumulative total $\mathrm{N}$ at the end of 13 weeks of incubation period; $\mathrm{N}_{\mathrm{o}}$ is the potential mineralizable nitrogen $\left(\mathrm{mg} \mathrm{kg}^{-1}\right)$; $\mathrm{k}$ is the nitrogen mineralization rate constant $\left(\mathrm{day}^{-1}\right)$; $\mathrm{t}$ is the incubation period in days.

The half-life ( $\left.\mathrm{t}_{1 / 2}\right)$ defined as the amount of time required for half of the organic $\mathrm{N}$ to be mineralized (Crohn, 2004; Karuku and Mochoge, 2018; Stanford et al. 1974) was determined using Equation 5 as given by Kakuru and Mochoge, 2018).

$$
\mathrm{t}_{1 / 2}=0.693 / \mathrm{k}
$$

Where, $\mathrm{t}^{1} / 2$ is the half-life in weeks; $\mathrm{k}$ is the mineralization rate constant.

The amount of mineralized nitrogen as a percentage of the total nitrogen applied to the soil was determined using Equation 6. 


$$
\% \mathrm{Nmin}=\{[(\mathrm{Ntf}-\mathrm{Ncf})-(\mathrm{Nti}-\mathrm{Nci})] / \mathrm{Nit}\} \times 100
$$

Where, \%Nmin is amount of mineralized nitrogen as a percentage of the total nitrogen applied; $\mathrm{N}_{\mathrm{tf}}$ is the cumulative total $\mathrm{N}\left(\mathrm{NH}_{4}{ }^{+}+\mathrm{NO}_{3}{ }^{-}\right)$in the amended soil after 13 weeks of incubation; $\mathrm{N}_{\mathrm{cf}}$ is the cumulative total $\mathrm{N}$ $\left(\mathrm{NH}_{4}^{+}+\mathrm{NO}_{3}{ }^{-}\right)$in the control (unamended soil) after 13 weeks of incubation; $\mathrm{N}_{\mathrm{ti}}$ is the initial total $\mathrm{N}\left(\mathrm{NH}_{4}^{+}+\right.$ $\left.\mathrm{NO}_{3}^{-}\right)$in the amended soil at the initial sampling; $\mathrm{N}_{\mathrm{ci}}$ is the initial total $\mathrm{N}\left(\mathrm{NH}_{4}^{+}+\mathrm{NO}_{3}^{-}\right)$in the control (unamended soil) at the initial sampling; $\mathrm{N}_{\mathrm{it}}$ is the initial organic $\mathrm{N}$ added to the soil.

\subsection{Data Analysis}

The statistical analysis was carried out by analysis of variance (ANOVA), while the treatment means were separated using the Duncan Multiple Range Test (DMRT). Standard deviation and correlation were calculated at the level of statistical significance of $\mathrm{P}<0.05$ using the SAS software version 9.0.

\section{Results}

\subsection{Estimated Amount of Biomass and N Returned to the Soil by the Organic Inputs}

The estimated amount of biomass and nitrogen that was returned to the soil by the different herbaceous species are presented in Table 4. The amount of biomass returned to the soil varied from year to year across the different organic inputs and across the two ARSs. No estimation of biomass was done for the shrubs (pigeon peas and tephrosia) in the first year as these species were still establishing. It should be noted that for the composted cattle manure, the 20 tons/ha was applied in two split applications of 10 tons/ha, one prior to planting and the other four weeks after the emergence of the main crop (maize).

Table 4. Estimated amount of biomass and associated estimates of $\mathrm{N}$ returned to the soil by the different organic inputs

\begin{tabular}{|c|c|c|c|c|c|}
\hline Site & Treatments & Year 1 & Year 2 & Year 3 & Average \\
\hline & & \multicolumn{4}{|c|}{ - Biomass in tons ha $^{-1}$ season $^{-1}$} \\
\hline \multirow{7}{*}{ Misamfu ARS } & $\mathrm{PpF} 1$ & - & $6.1(136)$ & $5.3(118)$ & $5.7(127)$ \\
\hline & $\mathrm{PpF}^{1 / 2}$ & - & $5.7(127)$ & $3.5(78)$ & $4.6(103)$ \\
\hline & TepF1 & - & $8.0(227)$ & $3.2(91)$ & $5.6(159)$ \\
\hline & $\mathrm{TepF}^{1 / 2}$ & - & $6.5(185)$ & $2.1(60)$ & $4.3(122)$ \\
\hline & $\operatorname{ModF}^{1 / 2}$ & $10.3(367)$ & $3.4(121)$ & $2.1(75)$ & $5.3(187)$ \\
\hline & ModF0 & $9.8(349)$ & $2.5(89)$ & $1.9(68)$ & 4.7 (169) \\
\hline & TradF1 & $20.5(228)$ & $2.1(23)$ & $1.8(20)$ & $8.1(90)$ \\
\hline \multirow{8}{*}{ Msekera ARS } & $\mathrm{PpF} 1$ & - & $6.5(145)$ & $4.5(100)$ & $5.5(123)$ \\
\hline & $\mathrm{PpF}^{1 / 2}$ & - & $5.7(127)$ & $3.4(76)$ & $4.6(103)$ \\
\hline & TepF1 & - & $8.2(233)$ & $5.3(151)$ & $6.8(192)$ \\
\hline & $\mathrm{TepF}^{1 / 2}$ & - & $8.3(236)$ & $4.3(122)$ & $6.3(179)$ \\
\hline & SunF1 & $6.0(191)$ & $7.8(248)$ & $4.7(150)$ & $6.2(196)$ \\
\hline & $\operatorname{SunF}^{1 / 2}$ & $3.5(111)$ & $6.8(216)$ & $4.3(137)$ & $4.9(155)$ \\
\hline & ManF0 & $20(374)$ & $20(374)$ & $20(374)$ & $20(374)$ \\
\hline & $\operatorname{ManF}^{1 / 2}$ & $20(374)$ & $20(374)$ & $20(374)$ & $20(374)$ \\
\hline
\end{tabular}

Note. Figures in parentheses indicate the estimated amounts of $\mathrm{N}$ that the different biomasses returned to the soil in $\mathrm{kg} / \mathrm{ha}$ calculated by multiplying the $\% \mathrm{~N}$ content of the biomass by the total amount of biomass produced.

\subsection{Nitrogen Mineralization}

The cumulative $\mathrm{N}$ mineralized $\left(\mathrm{N}_{\text {cum }}\right)$, the $\mathrm{N}$ mineralization rate constant $(\mathrm{k})$, the potentially mineralizable $\mathrm{N}\left(\mathrm{N}_{\mathrm{o}}\right)$, the $\mathrm{N}$ half-life $\left(t_{1 / 2}\right)$ and the percentage of applied $\mathrm{N}$ mineralized $\left(\% \mathrm{~N}_{\min }\right)$ are presented in Table 5. Significant differences $(p<0.05)$ were observed in the $\mathrm{N}_{\text {cum }}, \mathrm{k}, \mathrm{t}_{1 / 2}, \mathrm{~N}_{\mathrm{o}}$ and $\mathrm{N}_{\min }$ among treatments on both soils. The control treatments (Cont), consisting of soil alone, had the lowest $\mathrm{N}_{\text {cum }}$ and $\mathrm{N}_{\mathrm{o}}$ on both soils. All treatments recorded larger $\mathrm{k}$ values and consequently shorter $t_{1 / 2}$ than the control treatments on both soils. The TradF 1 treatment had significantly $(\mathrm{p}<0.05)$ higher $\mathrm{N}_{\text {cum }}$ and $\mathrm{N}_{\mathrm{o}}$ than the rest of the treatments on the LS while on the SCL soil, the ManF0 treatment had the highest $\mathrm{N}_{\mathrm{o}}$ which was however not significantly different from those of the ManF1/2 and SunF1 treatments. On the LS soil, the ModF $1 / 2$ recorded the highest percentage of applied $\mathrm{N}$ mineralized $\left(\% \mathrm{~N}_{\min }\right.$ of applied $\left.\mathrm{N}\right)$ which was significantly higher than the rest of the treatments with the exception of the $\mathrm{PpF}^{1 / 2}$ treatment. The amount of chemical fertilizer used had an influence on the $\mathrm{N}_{\text {cum }}$ on both soils with more 
$\mathrm{N}_{\text {cum }}$ recorded where more chemical fertilizer was applied. Generally, higher $\% \mathrm{~N}_{\min }$ values were observed where lower rates of chemical fertilizers were used on both soils. The composted manure (ManF0 and $\mathrm{ManF}^{1 / 2}$ ) on the SCL and the modified Fundikila (ModF0 and ModF¹/2) on the LS were the only exceptions to this.

Table 5. Mineralization rate constant, half-life, potentially mineralizable $\mathrm{N}$ and percentage of $\mathrm{N}$ mineralized on LS and SCL. Treatment means within a column followed by the same letters are not significantly different at 0.05 level of significance using Duncan's Multiple Range Test

\begin{tabular}{|c|c|c|c|c|c|}
\hline Treatment & $\mathrm{N}_{\text {cum }}\left[\mathrm{mg} \mathrm{kg}^{-1}\right]$ & $k\left[\right.$ week $\left.^{-1}\right]$ & $t_{1 / 2}[$ weeks $]$ & $\mathrm{N}_{\mathrm{o}}\left[\mathrm{mg} \mathrm{kg}^{-1}\right.$ soil $]$ & $\begin{array}{l}\text { Percentage of applied } \\
\mathrm{N} \text { mineralized }\left(\% \mathrm{~N}_{\min }\right)\end{array}$ \\
\hline \multicolumn{6}{|c|}{ Misamfu (Loamy sand) } \\
\hline Conv & $521.1 \mathrm{c}$ & $0.058 \mathrm{ab}$ & $12.3 \mathrm{bc}$ & $57.8 \mathrm{~b}$ & $16.2 \mathrm{e}$ \\
\hline PpF1 & $586.5 \mathrm{~b}$ & $0.051 \mathrm{abc}$ & $13.9 \mathrm{bc}$ & $67.1 b$ & $19.4 \mathrm{de}$ \\
\hline $\mathrm{PpF}^{1 / 2}$ & $569.9 \mathrm{~b}$ & $0.068 \mathrm{ab}$ & $10.5 \mathrm{c}$ & $59.2 \mathrm{~b}$ & $34.7 \mathrm{ab}$ \\
\hline TepF1 & $560.5 b c$ & $0.074 \mathrm{a}$ & $10.3 \mathrm{c}$ & $58.6 \mathrm{~b}$ & $17.2 \mathrm{de}$ \\
\hline $\mathrm{TepF}^{1 / 2}$ & $456.4 \mathrm{~d}$ & $0.065 \mathrm{ab}$ & $12.5 \mathrm{bc}$ & $55.6 \mathrm{~b}$ & $21.4 \mathrm{~cd}$ \\
\hline TradF1 & $697.6 \mathrm{a}$ & $0.043 \mathrm{bc}$ & $18.6 \mathrm{ab}$ & $87.2 \mathrm{a}$ & $25.0 \mathrm{c}$ \\
\hline $\operatorname{ModF}^{1 / 2}$ & $619.3 b$ & $0.051 \mathrm{abc}$ & $13.8 \mathrm{bc}$ & $70.5 b$ & $37.4 \mathrm{a}$ \\
\hline ModF0 & $582.9 \mathrm{~b}$ & $0.071 \mathrm{a}$ & $9.9 \mathrm{c}$ & $60.9 \mathrm{~b}$ & $31.7 \mathrm{~b}$ \\
\hline Cont & $239.0 \mathrm{e}$ & $0.033 \mathrm{c}$ & $22.0 \mathrm{a}$ & $30.5 \mathrm{c}$ & - \\
\hline \multicolumn{6}{|c|}{ Msekera (Sandy clay loam) } \\
\hline Conv & $449.2 d$ & $0.049 \mathrm{ab}$ & $15.7 \mathrm{~b}$ & $52.1 \mathrm{~d}$ & $8.8 \mathrm{e}$ \\
\hline PpF1 & $566.7 \mathrm{abc}$ & $0.054 \mathrm{ab}$ & $15.5 b$ & $67.2 \mathrm{bcd}$ & $14.8 \mathrm{~d}$ \\
\hline $\mathrm{PpF}^{1 / 2}$ & $548.7 \mathrm{bc}$ & $0.040 \mathrm{abc}$ & $18.1 \mathrm{~b}$ & $68.0 \mathrm{bcd}$ & $23.5 \mathrm{a}$ \\
\hline TepF1 & $602.3 \mathrm{ab}$ & $0.053 \mathrm{ab}$ & $13.9 \mathrm{~b}$ & $68.3 \mathrm{bcd}$ & $16.2 \mathrm{~cd}$ \\
\hline $\mathrm{TepF}^{1 / 2}$ & $509.9 \mathrm{~cd}$ & $0.065 \mathrm{a}$ & $12.5 b$ & $55.6 \mathrm{~cd}$ & $19.5 b c$ \\
\hline SunF1 & $628.7 \mathrm{a}$ & $0.053 \mathrm{ab}$ & $13.7 \mathrm{~b}$ & $70.7 \mathrm{abc}$ & $17.3 \mathrm{~cd}$ \\
\hline $\operatorname{SunF}^{1 / 2}$ & $545.8 \mathrm{bc}$ & $0.053 \mathrm{ab}$ & $13.4 \mathrm{~b}$ & $60.7 \mathrm{bcd}$ & $22.4 \mathrm{ab}$ \\
\hline $\mathrm{ManF}^{1} / 2$ & $621.2 \mathrm{a}$ & $0.043 \mathrm{abc}$ & $18.3 \mathrm{~b}$ & $77.1 \mathrm{ab}$ & $10.8 \mathrm{e}$ \\
\hline ManF0 & $582.2 \mathrm{ab}$ & $0.027 \mathrm{bc}$ & $26.9 \mathrm{a}$ & $85.2 \mathrm{a}$ & $10.0 \mathrm{e}$ \\
\hline Cont & 235.0 & $0.021 \mathrm{c}$ & $33.8 \mathrm{a}$ & $36.9 \mathrm{e}$ & - \\
\hline
\end{tabular}

Table 6 presents the $\mathrm{k}, \mathrm{t}_{1 / 2}$ and $\mathrm{N}_{\mathrm{o}}$ for grouped treatments on the two soils. The treatments were grouped in four categories at both sites. The "legume" group refers to the researcher-recommended modified Fundikila and the legume-cereal interplant systems of maize with Cajanus cajan, Crotalaria juncea and Tephrosia vogelii. The "traditional" group consisted of the composted cattle manure on the SCL and the traditional Fundikila, on the LS. The third and fourth categories consisted of the conventional and control treatments on both soils. The traditional group of treatments had significantly $(\mathrm{p}<0.05)$ the highest $\mathrm{N}_{\mathrm{o}}$ on both soils which was $186 \%$ and $120 \%$ higher than the control on the LS and SCL respectively. On both soils, the $\mathrm{N}_{\mathrm{o}}$ followed the order: traditional $>$ legumes $>$ conventional $>$ control while the $\mathrm{k}$ followed the order: legumes $>$ conventional $>$ traditional $>$ control. Although the $\mathrm{k}$ values for the control treatments were the lowest on both soils, they were, however, not significantly different from those of the traditional treatments. There were no significant differences in the $\mathrm{k}$ values between the legumes and the conventional treatments on both soils. When treatments were grouped based on soil type (Table 6), it was observed that the $\mathrm{k}$ was significantly higher $(\mathrm{p}<0.05)$ on the LS than on the SCL and consequently, the SCL had a significantly higher $t_{1 / 2}$ than the LS. No significant differences were observed in the $\mathrm{N}_{\mathrm{o}}$ between the two soils. 
Table 6. Mineralization rate constant, half-life and potentially mineralizable $\mathrm{N}$ for grouped treatments on the two soils. Treatment means within a column followed by the same letters are not significantly different at 0.05 level of significance using Duncan's Multiple Range Test

\begin{tabular}{|c|c|c|c|c|}
\hline Grouped treatments & $k\left[\right.$ week $\left.^{-1}\right]$ & $\mathrm{t}_{1 / 2}[$ weeks $]$ & $\mathrm{N}_{\mathrm{o}}\left[\mathrm{mg} \mathrm{kg}^{-1}\right]$ & $\begin{array}{l}\text { Percentage of applied } \\
\mathrm{N} \text { mineralized }\left(\% \mathrm{~N}_{\min }\right)\end{array}$ \\
\hline \multicolumn{5}{|l|}{ Misamfu (Loamy sand) } \\
\hline Control & $0.033 b$ & $22.0 \mathrm{a}$ & $30.5 \mathrm{c}$ & - \\
\hline Legumes & $0.063 \mathrm{a}$ & $11.8 \mathrm{~b}$ & $62.0 \mathrm{~b}$ & $27.0 \mathrm{a}$ \\
\hline Traditional & $0.043 \mathrm{ab}$ & $18.6 \mathrm{a}$ & $87.2 \mathrm{a}$ & $25.0 \mathrm{ab}$ \\
\hline Conventional & $0.058 \mathrm{a}$ & $12.3 b$ & $57.8 \mathrm{~b}$ & $16.2 b$ \\
\hline \multicolumn{5}{|c|}{ Msekera (Sandy clay loam) } \\
\hline Control & $0.021 b$ & $33.8 \mathrm{a}$ & $36.9 \mathrm{~d}$ & - \\
\hline Legumes & $0.053 \mathrm{a}$ & $14.5 \mathrm{c}$ & $65.1 \mathrm{~b}$ & $18.9 \mathrm{a}$ \\
\hline Traditional & $0.035 \mathrm{ab}$ & $22.6 b$ & $81.2 \mathrm{a}$ & $10.4 b$ \\
\hline Conventional & $0.049 \mathrm{a}$ & $15.7 \mathrm{c}$ & $52.1 \mathrm{c}$ & $8.8 \mathrm{~b}$ \\
\hline \multicolumn{5}{|l|}{ Summary based on site } \\
\hline Misamfu ARS (LS) & $0.057 \mathrm{a}$ & $13.7 \mathrm{~b}$ & $60.8 \mathrm{a}$ & $25.4 \mathrm{a}$ \\
\hline Msekera ARS (SCL) & $0.046 \mathrm{~b}$ & $18.2 \mathrm{a}$ & $64.2 \mathrm{a}$ & $15.9 b$ \\
\hline
\end{tabular}

\subsection{Urease Activities}

Urease activities in soils from the Msekera and Misamfu ARSs are presented in Table 7. There were no significant differences in urease activity across the different treatments at Msekera ARS. At Misamfu ARS, there was more urease activity where lower rates of chemical fertilizers were applied. For instance, the urease activity was $62 \%$ higher in the $\mathrm{PpF}^{1 / 2}$ as compared to the $\mathrm{PpF} 1$. Similarly, there was $42 \%$ higher urease activity in the $\mathrm{TepF}^{1 / 2}$ than in the TepF1. No significant differences were observed among all the treatments that received the full rate of chemical fertilizers, i.e., PpF1, TepF1, TradF1 and Conv at Misamfu ARS.

Table 7. Urease activity at Misamfu (LS) and Msekera (SCL) ARSs. Treatment means within a column followed by the same letters are not significantly different at 0.05 level of significance using Duncan's Multiple Range Test

\begin{tabular}{|c|c|}
\hline Treatment & Urease activity [ug $\mathrm{NH}_{4}-\mathrm{N} \mathrm{g}^{-1}$ soil $2 \mathrm{~h}^{-1}$ ] \\
\hline \multicolumn{2}{|c|}{ Misamfu ARS (Loamy sand) } \\
\hline Conv & $39.5 \mathrm{~b}$ \\
\hline PpF1 & $39.4 \mathrm{~b}$ \\
\hline $\mathrm{PpF}^{1 / 2}$ & 63.7 a \\
\hline TepF1 & $44.9 \mathrm{ab}$ \\
\hline $\mathrm{TepF}^{1} / 2$ & $63.7 \mathrm{a}$ \\
\hline TradF1 & $47.3 \mathrm{ab}$ \\
\hline $\operatorname{ModF}^{1 / 2}$ & $38.3 \mathrm{~b}$ \\
\hline ModF0 & $39.0 \mathrm{~b}$ \\
\hline \multicolumn{2}{|c|}{ Msekera ARS (Sandy clay loam) } \\
\hline Conv & $43.0 \quad \mathrm{a}$ \\
\hline PpF1 & 55.9 a \\
\hline $\mathrm{PpF}^{1 / 2}$ & 45.8 a \\
\hline TepF1 & 52.6 a \\
\hline $\mathrm{TepF}^{1 / 2}$ & $58.5 \mathrm{a}$ \\
\hline SunF1 & 46.7 a \\
\hline $\operatorname{SunF}^{1 / 2}$ & 51.4 a \\
\hline $\operatorname{ManF}^{1 / 2}$ & 50.9 a \\
\hline ManF0 & $56.2 \mathrm{a}$ \\
\hline
\end{tabular}




\subsection{Maize Yields}

The average maize yields from the two sites over the three growing seasons are presented in Figures $2 \mathrm{a}$ and $2 \mathrm{~b}$. For similar treatments, lower rates of chemical fertilizer resulted in lower maize yield across all the treatments in all the three years at both ARSs. At Msekera ARS, the combination of composted cattle manure with half rate of Compound $\mathrm{D}$ fertilizer ( $\mathrm{ManF}^{1 / 2}$ ) gave the highest maize yield which ranged from $26 \%$ to $137 \%$ higher than the conventional treatment in the three years (Figure 2a). Generally, the maize-legume interplant systems with full rate of chemical fertilizer produced higher yields than the conventional treatments in all the three years at Msekera ARS. At Misamfu ARS, for similar treatments, there was between $42 \%$ to $260 \%$ higher maize yield where higher rates of chemical fertilizer were applied. No maize yield data was recorded for the Fundikila treatments (TradF1, ModF $1 / 2$ and ModF0) at the Misamfu ARS in the first year of the trial as maize was only grown in the second year after breaking the Fundikila ridges. In the second year, the Fundikila treatments outperformed all the other treatments receiving organic inputs. ModF $1 / 2$ had the highest yield followed by the TradF1 at Misamfu ARS. A general decline in maize yield was observed across all treatments at ARSs in the third year.
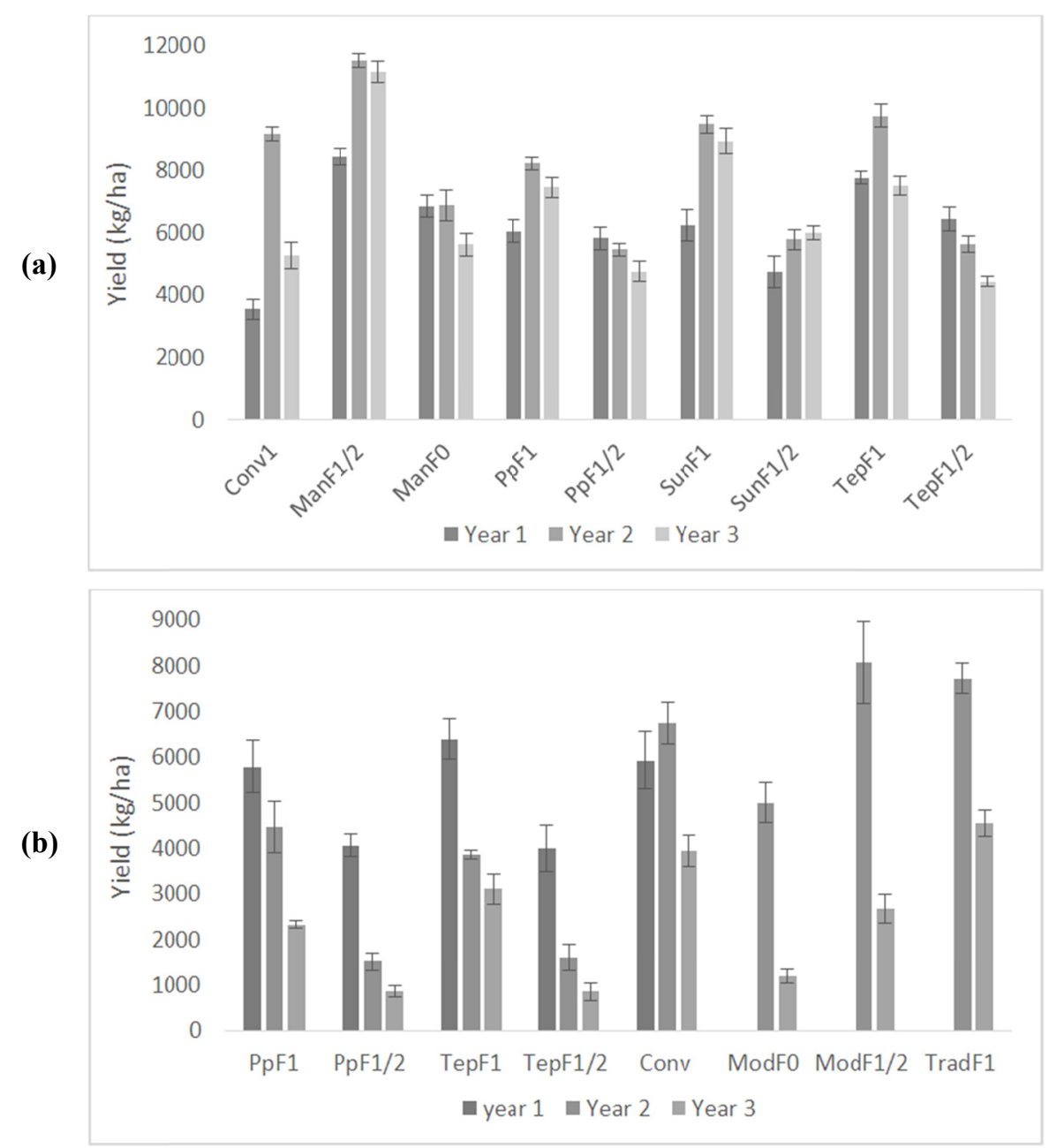

Figure 2. Average maize yield from Msekera ARS (a) and Misamfu ARS (b) over the three years of the field trials. Vertical bars indicate standard error

A comparison of maize yield for grouped treatments is shown in Table 8. The traditional treatment recorded the highest yields in all the three years at Msekera ARS, and in year 2 and 3 at Misamfu ARS. At Msekera ARS, maize yield from the traditional treatment was significantly higher $(\mathrm{p}<0.05)$ than the conventional treatment in year 1 and 3. No significant differences were observed across the three categories of treatments in year 2. At Misamfu ARS, there was no significant differences in maize yield between the traditional and conventional 
treatments in all the three years. The legume group of treatments had significantly lower $(p<0.05)$ maize yields that the other two groups of treatments in year 2 and 3.

Table 8. Average maize yield for grouped treatments. Treatment means within a column followed by the same letters are not significantly different at 0.05 level of significance using Duncan's Multiple Range Test.

\begin{tabular}{|c|c|c|c|c|c|c|}
\hline \multirow{3}{*}{ Grouped treatments } & \multicolumn{6}{|c|}{ Maize yield (kg/ha) } \\
\hline & \multicolumn{3}{|c|}{ Msekera ARS (SCL) } & \multicolumn{3}{|c|}{ Misamfu ARS (LS) } \\
\hline & Year 1 & Year 2 & Year 3 & Year 1 & Year 2 & Year 3 \\
\hline Traditional & $7662.0 \mathrm{a}$ & $9215.0 \mathrm{a}$ & $8391.0 \mathrm{a}$ & - & $7723.0 \mathrm{a}$ & $4553.5 \mathrm{a}$ \\
\hline Legumes & $6183.9 a$ & $7404.0 \mathrm{a}$ & $6533.0 \mathrm{ab}$ & $5941 \mathrm{a}$ & $4091.0 \mathrm{~b}$ & $1845.8 \mathrm{~b}$ \\
\hline Conventional & $3566.5 b$ & $9193.0 \mathrm{a}$ & $5371.0 \mathrm{~b}$ & $5073 a$ & $6767.0 \mathrm{ab}$ & $3942.1 \mathrm{a}$ \\
\hline
\end{tabular}

The regression analysis of maize yield against $t_{1 / 2}$, urease activity, $\% \mathrm{~N}_{\min }$ and $\mathrm{N}_{\text {cum }}$ is presented in Table 9 . There was a significant correlation between maize yield, $\% \mathrm{~N}_{\min }$ and $\mathrm{N}_{\text {cum }}$ on both soils. At Msekera ARS, maize yield was also significantly correlated to $t_{1 / 2}$ ( $p$ value of 0.0031 ). An inverse relationship was observed between maize yield and $\% \mathrm{~N}_{\min }$ at both ARSs (parameter estimates of -120.79 and -265.67 at Misamfu and Msekera ARS respectively), i.e., the higher the amount of applied $\mathrm{N}$ mineralized, the lower the maize yield, and vice-versa. A similar trend was observed between the $t_{1 / 2}$ and the maize yield at Msekera ARS (parameter estimate of -138.17), i.e., the longer the time for half of the $\mathrm{N}$ to be mineralized, the lower the yield. No significant relationship was observed between urease activity and maize yield at both sites. Similarly, maize yield was not significantly correlated with $t_{1 / 2}$ at Misamfu ARS.

Table 9. Regression analysis of maize yield against $\mathrm{t}_{1 / 2}$, urease activity, $\% \mathrm{~N}_{\min }$ and $\mathrm{N}_{\text {cum }}$

\begin{tabular}{llllll}
\hline Variable & DF & Parameter estimate & Standard error & t-value & $\mathrm{p}$ \\
\hline Misamfu (Loamy sand) & & & & & \\
Intercept & 1 & -2881.80 & 2205.57 & -1.31 & 0.2024 \\
$\mathrm{t}_{1 / 2}$ & 1 & 11.36 & 54.78 & 0.21 & 0.8373 \\
Urease activity & 1 & 2.64 & 15.35 & 0.17 & 0.8647 \\
$\% \mathrm{~N}_{\text {min }}$ & 1 & -120.79 & 31.97 & -3.78 & 0.0008 \\
$\mathrm{~N}_{\text {cum }}$ & 1 & 14.15 & 4.04 & 3.50 & 0.0016 \\
$\mathrm{R}$-square & 0.46 & & & & \\
\hline Msekera (Sandy clay loam) & & & & \\
Intercept & 1 & 1222.68 & 2380.05 & 0.51 & 0.6111 \\
$\mathrm{t}_{1 / 2}$ & 1 & -138.17 & 43.07 & -3.21 & 0.0031 \\
Urease activity & 1 & -7.59 & 16.97 & -0.45 & 0.6579 \\
$\% \mathrm{~N}_{\text {min }}$ & 1 & -265.67 & 51.98 & -5.11 & $<0.0001$ \\
$\mathrm{~N}_{\text {cum }}$ & 1 & 23.21 & 4.10 & 5.65 & $<0.0001$ \\
$\mathrm{R}$-square & 0.61 & & & & \\
\hline
\end{tabular}

\section{Discussion}

\subsection{Effect of Organic Inputs on Nitrogen Mineralization}

Organic inputs with or without chemical fertilizer resulted in higher $\mathrm{N}_{\text {cum }}$ and $\mathrm{N}_{\mathrm{o}}$ than chemical fertilizer alone (Conv) or soil alone (Cont). On the loamy sand (LS) soil, values for $\mathrm{N}_{\mathrm{o}}$ were $127 \%$ to $256 \%$ significantly higher $(p<0.05)$ where organic inputs had been applied as compared to the control. The $\mathrm{N}_{\mathrm{o}}$ for treatments receiving organic inputs on the sandy clay loam (SCL) soil was $51 \%$ to $131 \%$ significantly higher than the control. Similarly, values for $\mathrm{N}_{\text {cum }}$ for treatments receiving organic inputs were twice or thrice higher than control treatments on both soils. These results corroborate findings by Bhat et al. (2015) who established that application of organic inputs either alone or in combination with chemical fertilizers resulted in $19 \%$ to $73 \%$ more $\mathrm{N}_{\mathrm{o}}$ than the control and $11 \%$ to $57 \%$ more $\mathrm{N}_{\mathrm{o}}$ than conventional treatments. The results further support findings by Kalala, Shitumbanuma, Adamtey and Benson (2020) who, working with the same soils and same inputs used in this study, established that the addition of organic inputs with or without chemical fertilizer resulted in higher carbon emissions ranging from 81 to $129 \%$ and 18 to $34 \%$ than control treatments on LS and SCL soils respectively. 
This close relationship between the $\mathrm{N}_{\mathrm{o}}$ and $\mathrm{N}_{\text {cum }}$ with $\mathrm{CO}_{2}$ emissions is supported by Hons, Haney and Franzluebbers (2002) who state that since $\mathrm{N}$ mineralization is as a result of $\mathrm{C}$ oxidation, the evolution of $\mathrm{CO}_{2}$ can thus be used as an estimator of soil $\mathrm{N}$ mineralization. The legume group of treatments had the largest $\% \mathrm{~N}_{\min }$ and the highest $\mathrm{k}$ and consequently the shortest $\mathrm{t}_{1 / 2}$ on both soils. This could be largely as a result the chemical composition of the legume biomass. Naturally, legumes tend to have lower $\mathrm{C} / \mathrm{N}$ ratios than most other plant materials (Table 4). The composted cattle manure, despite having a relatively lower $\mathrm{C} / \mathrm{N}$ ratio, had one of the lowest $\% \mathrm{~N}_{\min }$ which was significantly lower than all the other organic inputs on the SCL. This, as stated by Kalala et al. (2020) could be as a result of the presence of more recalcitrant carbon as most of the labile carbon might have been removed during the composting process.

\subsection{Effect of Chemical Fertilizer on Nitrogen Mineralization}

Application of chemical fertilizer without any organic inputs (conventional treatment) significantly increased both $\mathrm{k}$ and $\mathrm{N}_{\mathrm{o}}$ in comparison to the control treatments on both soils (Table 5). The $\mathrm{N}_{\mathrm{o}}$ of the conventional treatment was $136 \%$ higher than the control on the LS and $41 \%$ higher than the control on the SCL. These results corroborate findings by Zhang et al. (2012) who found that application of chemical fertilizer increased N mineralization rate as a result of the lowering of the soil $\mathrm{C} / \mathrm{N}$ ratio by the chemical fertilizer leading to enhanced microbial decomposition of the native soil organic matter (Zhang et al., 2012). The high cumulative $\mathrm{N}$ mineralized $\left(\mathrm{N}_{\text {cum }}\right)$ observed in treatments receiving higher rates of chemical fertilizer on both soils could have been as a result of the "priming effect" of the chemical fertilizer on both the soil and the applied organic N. The high cumulative $\mathrm{N}$ associated with higher rates of chemical fertilizer might be a concern for agricultural production as the rate of $\mathrm{N}$ mineralization might exceed the rate of crop $\mathrm{N}$ uptake resulting in a net $\mathrm{N}$ loss and environmental pollution. As stated by Barker (2017), the use of chemical fertilizer in conventional farming systems can lead to a net loss of up to $70 \%$ of applied nitrogen.

\subsection{Effect of Soil Type on N Mineralization}

Nitrogen mineralization was generally faster on the LS than on the SCL and consequently, it would take about 5 weeks less for half of the organic $\mathrm{N}$ to be mineralized on the LS than on the SCL (Table 6). Similarly, the $\% \mathrm{~N}_{\min }$ on the LS was about $60 \%$ more than that on the SCL. These observations agree with findings by Cassity-Duffey, Cabrera, Franklin, Gaskin, and Kissel (2020) who established that the net N mineralized was lower in soils with a higher clay content. Similarly, Mubarak, Gali, Mohamed, Steffens and Awadelkarim (2010) reported net N mineralization in light soils to be 2.5 to 6 times higher than in heavy soils. This, according to Kalala et al. (2020) could be as a result of the protective effect of clay on soil organic matter decomposition.

\subsection{Effect of Soil Fertility Management Practices on the Activities of Urease Enzyme}

Generally, there was more urease activity where lower rates of chemical fertilizer were applied on both soils. This was particularly evident at Misamfu ARS where significant differences were observed as a result of the different rates of chemical fertilizer. These results are in accord with Sekaran et al. (2019) who also found that urease activity was higher where half rate of chemical N (56 kg/ha) was applied. Similarly, Balezentiene and Klimas (2009), and Omenda et al. (2019) also established that urease activities increased in soils fertilized with either animal or green manures and decreased where chemical fertilizer was applied. Raju et al. (2013) found that combination of chemical fertilizer with organic inputs resulted in 4 to $77 \%$ more urease activity in comparison to application of chemical fertilizer alone. In our study, addition of organic inputs with or without chemical fertilizer resulted in $7 \%$ to $36 \%$ more urease activity than the conventional treatment on the SCL soil. On the LS, with the exception of the PpF1, ModF0 and ModF $1 / 2$ treatments whose urease activity was lower (though not significantly) than the conventional treatment, the other treatments that received organic inputs had 13 to $61 \%$ more urease activity than the conventional treatment.

\subsection{Effect of Soil Fertility Management Practices on Maize Yield}

Results from Msekera ARS revealed that higher maize yields were obtained from the combination of organic inputs with higher rates of chemical fertilizer as opposed to the sole application of chemical fertilizer (Conv), or the combination of organic inputs with lower rates of chemical fertilizers. The lower yields associated with the combined application of organic inputs with lower or zero rates of chemical fertilizer at both ARSs are indicative of the fact that organic inputs, due to their slow decomposition rates might not be adequate to supply the required crop nutrients in the short-term. Additionally, in the first year, there was no organic matter returned to the soil from the leguminous shrubs, i.e., the pigeon pea and tephrosia at both ARSs (Table 2) implying that the maize crop in these treatments was solely supported by the nutrients from the chemical fertilizer. These findings are in accordance with Nyamaranga, Mudhara, and Giller (2005) who established that in the short-term, maize yields tend to be higher were organic inputs are used in combination with chemical fertilizer as opposed to the sole use 
of organic inputs. The three-year average maize yield at Msekera ARS was 21\% to 37\% higher in treatments where the full rate of chemical fertilizer was used in combination with organic inputs than the conventional treatment. This observation has been reported elsewhere and could be attributed to the additional nutrients from the organic inputs as well the enhanced nutrient retention capacity by the organic matter (Nyamaranga et al., 2005).

The relatively lower yields associated with the maize-legume interplants at the Misamfu ARS in comparison to the conventional treatment might have been largely as a result of the competition between the legume species and the maize. Misamfu ARS, being in agro-ecological region III of Zambia, is characterized by high amounts of annual rainfall that stimulated rapid growth of the legume species at the expense of the maize crop. Similar to our findings, Rusinamhodzi, Corbeels, Nyamangara, and Giller (2012) found that interplanting maize with legume in distinct rows resulted in a net decline in maize yield of about $10 \%$ compared to maize planted as a sole crop.

The high maize yield recorded by the traditional group of treatments at both agricultural research stations could have been as a result of the high amounts of biomass that these treatments returned to the soil (Table 4) which in turn resulted in the highest $\mathrm{N}_{\text {cum }}$ and $\mathrm{N}_{\mathrm{o}}$ (Tables 5 and 6). The high $\mathrm{N}_{\text {cum }}$ and $\mathrm{N}_{\mathrm{o}}$ might have translated in more $\mathrm{N}$ uptake by the maize crop in these treatments. These results corroborate findings by Beah et al. (2015) who established that increased application of organic inputs resulted in an increase in nitrogen uptake by plants. The relationship between maize yield and $\mathrm{N}_{\text {cum }}$ is further confirmed by the highly significant positive correlation ( $\mathrm{p}<$ 0.05 ) between maize yield and $\mathrm{N}_{\text {cum }}$ at both sites (Table 9), i.e., an increase in $\mathrm{N}_{\text {cum }}$ leads to an increase in maize yield.

\section{Conclusion}

Nitrogen mineralization was greatly influenced by the application of organic inputs with more $\mathrm{N}$ being mineralized where organic inputs were applied in comparison to the soil alone (control) or where only chemical fertilizer was applied. Among the organic inputs, higher rates of $\mathrm{N}$ mineralization were observed where legumes were applied as opposed to the traditional organic inputs (native shrubs and grass or composted cattle manure). More $\mathrm{N}$ was mineralized where higher rates of chemical fertilizer were applied in combination with organic inputs, and consequently, higher yields of maize were obtained from the combined application of organic inputs with higher rates of chemical fertilizers. The influence of soil texture on $\mathrm{N}$ mineralization was very evident as higher $\mathrm{N}$ mineralization rates were obtained on the loamy sand soil than on the sandy clay loam. Urease activity was stimulated by the application of organic inputs and suppressed at higher rates of chemical fertilizer. Thus, this paper contributes to the evidence that: (i) the application of organic inputs whether alone or in combination with chemical fertilizer enhances $\mathrm{N}$ mineralization; (ii) the application of chemical fertilizer suppresses urease activity; (iii) the rate of $\mathrm{N}$ mineralization is faster on lighter soils than heavier ones; (iv) the combined application of organic inputs and chemical fertilizer gives higher maize yields than the sole application of either of the two inputs.

\section{Acknowledgements}

The authors gratefully acknowledge the financial support received from the Swiss Programmed for Research on Global Issues for Development and the Swiss National Science Foundation through the Research Institute of Organic Agriculture (FiBL) for this study. The authors would also love to express gratitude to the following laboratory and field technical staff: Aton Kuhn from the Research Institute of Organic Agriculture (FiBl); Gideon Musukwa from the Soil Sciences laboratory at the University of Zambia; Mwambazi Chilala and Mwindilila Chisango from the Zambia Agricultural Research Institute.

\section{References}

Amin, M., \& Flowers, T. H. (2004). Evaluation of the Kjeldhal Method. J Res Sci, 15(2), 159-179.

Anderson, J. M., \& Ingram, J. S. I. (1993). Tropical soil biology and fertility: A handbook of methods. Soil Science, 157(4), 265. https://doi.org/10.2307/2261129

Balezentiene, L., \& Klimas, E. (2009). Effect of Organic and Mineral Fertilizers and Land Management on Soil Enzyme Activities. Agronomy Research, 7(SP I), 191-197. https://doi.org/oai:portalcris.vdu.lt:20.500. $12259 / 81782$

Barker, S. E. (2017). Effects of Fertilizer and Shade Management on Nitrogen Mineralization, Nitrifying Microbial Abundance and Nitrogen-Fixing Capacity of Erythrina Poeppigiana in Coffee (Coffea Arabica) Agroforestry Systems in Costa Rica. (Electronic Theses and Dissertations). Retrieved from https://digitalcommons.georgiasouthern.edu/etd/1541 
Beah, A. A., Norman, P. E., Scholberg, J. C., Lantinga, E. A., \& Conteh, A. R. (2015). Effect of Organic Manure on Nitrogen Mineralization, Nitrogen Accumulation, Nitrogen Use Efficiency and Apparent Nitrogen Recovery of Cauliflower (Braccica Oleracea L., Var. Botrytis). International Journal of Plant \& Soil Science, 4(3), 265-272. https://doi.org/10.9734/IJPSS/2015/12660

Benedetti, A., \& Sebastiani, G. (1996). Determination of Potentially Mineralizable Nitrogen in Agricultural Soil. Biol Fertil Soils, 21, 114-120. https://doi.org/10.1007/BF00336002

Bhat, Z. A., Saroa, G. S., Benbi, D. K., Choudary, O. P., \& Padder, S. A. (2015). Nitrogen Mineralization Kinetics in Soils Incubated at Different Temperatures Amended with Organic and Inorganic Fertilizers. The Ecoscan, 9(3\&4) 699-703.

Cassity-Duffey, K., Cabrera, M., Franklin, D., Gaskin, J., \& Kissel, D. (2020). Effect of Soil Texture on Nitrogen Mineralization from Organic Fertilizers in Four Common South-Eastern Soils. Soil Science Society of America, 84(2), 534-542. https://doi.org/10.1002/saj2.20039

Crohn, D. (2004). Nitrogen Mineralization and its Importance in Organic Waste Recycling. Proceedings of National Alfalfa Symposium. San Diego, CA, UC Cooperative Extension, University of California. Retrieved from http://alfalfa.usdavis.edu

Dilly, O., Blume, H. P., \& Munch, J. C. (2003). Soil Microbial Activities in Luvisols and Anthrosols during 9 Years of Region-Typical Tillage and Fertilization Practices in Northern Germany. Biogeochem., 65(3), 319-339. https://doi.org/10.1023/A:1026271006634

Hart, S. C., Stark, J. M., Davidson, E. A., \& Firestone, M. K. (1994). Nitrogen Mineralization, Immobilization, and Nitrification. In R. W. Weaver, S. Angle, P. Bottomley, D. Bezdicek, S. Smith, A. Tabatabai, \& A. Wollum (Eds.), Methods of Soil Analysis: Part 2 Microbiological and Biochemical Properties, 5.2. Soil Science Society of America, Inc. https://doi.org/10.2136/sssabookser5.2

Hons, F. M., Haney, R. L., \& Franzluebbers, A. (2002). An Innovative Soil Test for Predicting Nitrogen Mineralization (USDA-ARS/UNL Faculty, Paper 1055). USDA Agricultural Research Service, Lincoln, Nebraska. Retrieved from http://digitalcommons.unl.edu/usdaarsfacpub/1055

Insam, H. (2001). Developments in Soil Microbiology since the Mid-1960s. Geoderma, 100(3-4), $389-402$. https://doi.org/10.1016/S0016-7061(01)00029-5

Jones, J. B. (2001). Laboratory guide for conducting soil tests and plant analysis. CRS Press, Florida. https://doi.org/10.1201/9781420025293

Kalala, D. M., Shitumbanuma, V., Adamtey, N., \& Benson, H. C. (2020). Organic Inputs and Chemical Fertilizer on Carbon Mineralization from two Ultisols. Journal of Agricultural Science, 12(11), 223-233. https://doi.org/10.5539/jas.v12n11p223

Kandeler, E., \& Gerber, H. (1988). Short-term Assay of Soil Urease Activity using Colorimetric Determination of Ammonium. Biology and Fertility of Soils, 6, 68-72. https://doi.org/10.1007/BF00257924

Karuku, G. N., \& Mochoge, B. O. (2018). Nitrogen Mineralization Potential (No) in Three Kenyan Soils, Nitisols, Ferralsols and Luvisols. Journal of Agricultural Science, 10(4), 69-78. https://doi.org/10.5539/ jas.v10n4p69

Kiboi, M. N., Ngetich, F. K., \& Mugendi, D. N. (2019). Nitrogen Budgets and Flows in African Smallholder Farming Systems. AIMS Agriculture and Food, 4(2), 429-446. https://doi.org/10.3934/agrfood.2019.2.429

Magai, R. N. (1985). Field tour guide. In P. R. Woode (Ed.), Proceedings of the 11th international forum on soil taxonomy and agrotechnological transfer, July 15 to August 1, 1985, Zambia. IBSNAT, BADC, MAWD, NORAD, USAID, SMSS, UNZA.

Mikha, M. M., Rice, C. W., \& Benjamin, J. G. (2006). Estimating Soil Mineralizable Nitrogen under Different Management Practices. Soil Sci. Soc. Am. J., 70, 1522-1531. https://doi:10.2136/sssaj2005.0253

Mubarak, A. R., Gali, E. A. M., Mohamed, A. G., Steffens, D., \& Awadelkarim, A. H. (2010). Nitrogen Mineralization from Five Manures as Influenced by Chemical Composition and Soil Type. Communications in Soil Science and Plant Analysis, 41(16), 1903-1920. https://doi.org/10.1080/00103624.2010.495802

Nelson, D. W., \& Sommers, L. E. (1982). Organic carbon. In A. L. Page, R. H. Miller, D. R. Keeney (Eds.), Methods of Soil Analysis, Part 2: Chemical and Biological Properties (2nd ed., pp. 199-224). Am Soc Agron, Madison. https://doi.org/10.2134/agronmonogr9.2.2ed 
Nyamaganra, J., Mudhara, M., \& Giller, K. E. (2005). Effectiveness of Cattle Manure and Nitrogen Fertilizer Application on the Agronomic and Economic Performance of Maize. S. Afr. J. Plant Soil, 22(1), 59-63. https://doi.org/10.1080/02571862.2005.10634682

Omenda, J. A., Ngetich, K. F., Kiboi, M. N., Mucheru-Muna, M. W., \& Mugendi, D. N. (2019). Soil Organic Carbon and Acid Phosphatase Enzyme Activity Response to Phosphate Rock and Organic Inputs in Acidic Soils of Central Highlands of Kenya in Maize. International Journal of Plant \& Soil Science, 30(2), 1-13. https://doi.org/10.9734/IJPSS/2019/v30i230169

Piotrowska-Dlugosz, A. (2014). Enzymes and soil fertility. In L. Gianfreda \& M. A. Rao (Eds.), Enzymes in agricultural sciences. Omics Group, Foster City. Retrieved from https://www.esciencecentral.org/ebooks

Raju, B., Rao, P. C., Reddy, A. P. K., \& Padmavathi, P. (2013). Effect of Various INM Practices on Yield, Urease and Dehydrogenase Activity in Safflower. Helix, 6, 405-408.

Rusinamhodzia, L., Corbeels, M., Nyamangara, J., \& Giller, K. E. (2012). Maize-Grain Legume Intercropping is an Attractive Option for Ecological Intensification that Reduces Climatic Risk for Smallholder Farmers in Central Mozambique. Field Crops Research, 136, 12-22. https://doi.org/10.1016/j.fcr.2012.07.014

Schumacher, B. A. (2002). Methods for the determination of total organic carbon (toc) in soils and sediments. US Environmental Protection Agency, Washington.

Sekaran, U., McCoy, C., Kumar, S., \& Subramanian, S. (2019). Soil Microbial Community Structure and Enzymatic Activity Responses to Nitrogen Management and Landscape Positions in Switchgrass (Panicum virgatum L.). GCB Bioenergy, 11, 836-851. https://doi.org/10.1111/gcbb.12591

Srinivasa-Rao, C., Grover, M., Kundu, S., \& Desai, S. (2017). Soil enzymes. In R. Lal (Ed.), Encyclopedia of Soil Science (3rd ed.). Taylor \& Francis. https://doi.org/10.1081/E-ESS3-120052906

Stanford, G., Carter, J. N., \& Smith, S. J. (1974). Estimates of Potentially Mineralizable Soil Nitrogen Based on Short-Term Incubations. Soil Sci. Soc. Amer. Proc., 38(1). https://doi.org/10.2136/sssaj1974.03615995003 $800010031 \mathrm{x}$

Veldkamp, W. J. (1987). Soils of Zambia (2nd ed., Soil Bulletin No. 13). Soil Survey Unit-Research Branch, Department of Agriculture.

Zhang, X., Wang, Q., Gilliam, F. S., Bai, W., Han, X., \& Li, L. (2012). Effect of nitrogen fertilization on net nitrogen mineralization in a grassland soil, northern China. Grass and Forage Science, 67(2), 219-230. https://doi.org/10.1111/j.1365-2494.2011.00836.x

\section{Copyrights}

Copyright for this article is retained by the author(s), with first publication rights granted to the journal.

This is an open-access article distributed under the terms and conditions of the Creative Commons Attribution license (http://creativecommons.org/licenses/by/4.0/). 